\title{
Vote Brokerage, Personal Networks, and Agency Loss
}

In the previous chapter, I showed that the targeting strategy used by Indonesian legislative candidates that combines the party loyalist strategy and personal networks makes vote buying tremendously inefficient. Candidates and brokers plan to target party loyalists, but in reality, most vote buying happens among uncommitted voters. In this chapter, I argue that such vote-buying efforts not only suffer from inefficiency of delivery, but are also undermined by a substantial amount of 'leakage,' given the intrinsic principal-agent problems that arise in the relations between candidates and brokers. I show that most candidates lack mechanisms to systematically monitor or discipline their brokers, making vote-buying attempts vulnerable to broker predation. I also provide empirical evidence of rent-seeking behaviours by brokers, drawing on a unique survey of brokers.

But if vote brokerage is subject to rent-extraction, this doesn't mean that all brokers are equally untrustworthy and unreliable. The available body of research on electoral clientelism in Indonesia clearly demonstrates that vote brokerage-which relies on personal networks-remains critical to electoral success, given brokers' significance in expanding candidates' electoral base and distributing material inducements. Overall, I argue that despite the inherent weaknesses of vote buying using personal networks, these networks really matter in shaping how vote buying works, which brokers are recruited, and how targeting occurs. This chapter accordingly aims to explore brokerage networks - who the brokers are and what drives

(C) The Author(s) 2019

B. Muhtadi, Vote Buying in Indonesia, https://doi.org/10.1007/978-981-13-6779-3_6 
them to join a candidate's success team. It also discusses the logistics of vote buying, such as how candidates recruit and monitor brokers and how brokers determine what, when, and how much money to give. It seeks to answer these and related questions through an examination of my field research findings and data produced by my broker and candidate surveys, as well as voter surveys from Indonesia's 2014 elections.

\subsection{How Many Brokers Are There in Indonesia?}

My unique survey of a probability sample of vote brokers provides information about the estimated population of brokers in West Sumatra, East Java, Central Java, and North Sulawesi. As I explain in Chap. 1, the selection of these four provinces was primarily guided by the fit of cases with the statistical findings of large-scale surveys in 73 out of 77 electoral districts across Indonesia. I then selected these four provinces to reflect variations in levels of mass partisanship and vote buying across Indonesia.

Table 6.1 illustrates that relative to other provinces, Central Java is slightly wealthier and has slightly better life expectancy and human development scores than the average, but in terms of literacy rates and number of school years completed, it is below the national average. In East Java, the patterns are broadly similar to Central Java, with the exception in terms of life expectancy; East Java is marginally behind the national average. Although much of North Sulawesi and West Sumatra do relatively

Table 6.1 Demographic profile of four provinces

\begin{tabular}{llllll}
\hline Province & $\begin{array}{l}\text { Life } \\
\text { expectancy } \\
\text { (years) }\end{array}$ & $\begin{array}{l}\text { Literacy } \\
(\%)\end{array}$ & $\begin{array}{l}\text { Average years } \\
\text { of school } \\
\text { completed }\end{array}$ & $\begin{array}{l}\text { Adjusted per capita } \\
\text { expenditure (in } \\
\text { thousands of rupiah) }\end{array}$ & $\begin{array}{l}\text { Human } \\
\text { development } \\
\text { index }\end{array}$ \\
\hline $\begin{array}{l}\text { Central } \\
\text { Java }\end{array}$ & 70.8 & 91.6 & 7.7 & 644.2 & 73.3 \\
$\begin{array}{l}\text { East Java } \\
\begin{array}{l}\text { North } \\
\text { Sulawesi }\end{array}\end{array}$ & 68.8 & 90 & 7.7 & 643.7 & 71.9 \\
$\begin{array}{l}\text { West } \\
\text { Sumatra }\end{array}$ & 69.2 & 99.4 & 8.7 & 631.2 & 75.4 \\
$\begin{array}{l}\text { Indonesia } \\
\text { Ind }\end{array}$ & 68.9 & 97.7 & 8.8 & 635 & 73.9 \\
\hline
\end{tabular}

Source: http://data.go.id/dataset/ipm-dan-komponennya-per-kabupaten

Note: All data from 2012 
well in terms of life expectancy, literacy, number of school years completed, and human development scores, both score badly on average monthly per capita expenditure. In socio-cultural and political terms, Central Java is widely known as the secular PDI-P's primary stronghold with a mixed population of abangan, socio-economically lower-class nominal Muslims, as well as more pious santri Muslims with traditionalist Islamic backgrounds (Geertz, 1960). While East Java is a centre of NU-style traditional Islam, it also has a large concentration of abangan in the southern part of the province. West Sumatra is the home of Islamic modernists, who adhere to orthodox Islam while accepting modern ideas, and it provides the strongest support outside Java to the biggest modernist organisation, Muhammadiyah. North Sulawesi is predominantly Protestant with a sizeable Catholic minority and is recognised as a stronghold of both PDI-P and Golkar. In terms of political alignments, by contrast, East Java and West Sumatra are categorised as 'swing' regions with no single party dominating.

As already explained in Chap. 1, my research began with a face-to-face survey of a probability sample of 299 elected candidates for provincial and regent/district DPRD electoral districts in four provinces. Then, for every randomly selected DPRD member, three of their brokers who helped them during the 2014 election were also randomly selected, making about 900 brokers in total interviewed. The population of brokers in each region was, of course, unknown because brokerage teams are informal and unregistered. To determine the broker population, I made an estimate based on the average number of brokers mentioned by local MP respondents. Hence, the sample in four provinces reached a total of 1199 respondents consisting of 100 provincial DPRD members, 300 brokers of provincial DPRD candidates, 199 Regent/City DPRD candidates, and 600 brokers of Regent/ City DPRD candidates (one sampled district DPRD member cannot be interviewed within the field duration, but his brokers were given permission to participate in this survey). I personally administered these unique, representative surveys of elected candidates and brokers from September to October 2014 (for more information about these surveys, see Appendix B). To my knowledge, mine is the largest and most detailed survey of candidates and brokers undertaken to date anywhere in clientelism research. ${ }^{1}$

\footnotetext{
${ }^{1}$ For comparison, Stokes and her collaborators conducted a survey in 2009 of about 800 councillors and non-elected brokers in four Argentine regions-the provinces of Cordoba, Misiones, San Luis, and the Greater Buenos Aires (see Stokes et al., 2013).
} 
Table 6.2 presents the survey results, showing the average number of brokers by province. There is considerable variation. In each province, the average number of brokers for provincial legislature (DPRD I) candidates is greater than the average number for district legislature (DPRD II) candidates. This gap is largely because the electoral districts at the provincial level are larger and their populations are greater, which in turn necessitates a larger number of brokers. It is important to note that in Java, the boundaries of the national and provincial electoral districts coincide (Aspinall and Sukmajati, 2016: 15). Broker armies in both Central Java and East Java were large, and vote-buying strategies were extensively pursued in both provinces. This finding contrasts with the normal expectation. Previous works argued that the greater the size of the electoral constituency, the lower the likelihood of clientelist strategies being pursued (Stokes, 2007; Hicken, 2007). However, my survey findings pointing to large brokerage networks in Central and East Java correspond with general findings from my pre-election surveys in all electoral districts of these two provinces, which suggests that voters in these provinces were more likely to view vote buying as a normal practice (see Chap. 1).

Consistent with prior expectations, the brokerage networks in West Sumatra were much simpler relative to other regions. Instead of utilising large networks of brokers for grassroots campaigning, most elected candidates in the province instead drew on traditional leadership structures, known locally as tungku tigo sajarangan (the three stoves at the hearth), that comprises three pillars: adat or clan elders (ninik-mamak), religious leaders (alim-ulama), and cadiak pandai (enlightened intellectuals). Where they could, candidates approached and recruited these people into their personal teams (Edi Inrizal, Interview, 21 September 2014). This qualitative evidence parallels my voter survey results in West Sumatra, indicating that the level of vote buying in the province was much lower than in other regions in Indonesia, presumably largely because candidates were instead relying partly on the informal influence exercised by these community leaders.

Table 6.2 The average number of brokers per candidate

\begin{tabular}{lrr}
\hline Province & DPRDI & DPRD II \\
\hline West Sumatra & 44.3 & 22.8 \\
Central Java & 416.5 & 126.5 \\
East Java & 339.3 & 195.3 \\
North Sulawesi & 426.7 & 97.7 \\
\hline
\end{tabular}


Table 6.3 Estimated broker population in four provinces

\begin{tabular}{lrrrrr}
\hline Province & \multicolumn{3}{c}{ DPRDI } & \multicolumn{3}{c}{ DPRD II } & \multirow{2}{*}{ Total } \\
\cline { 2 - 5 } & Legislators & Brokers & Legislators & Brokers \\
\hline West Sumatra & 65 & 2880 & 575 & 13,118 & 16,638 \\
Central Java & 100 & 41,647 & 1570 & 198,622 & 241,940 \\
East Java & 100 & 33,927 & 1675 & 327,098 & 362,801 \\
North Sulawesi & 45 & 19,203 & 390 & 38,084 & 57,721 \\
Total & 310 & 97,657 & 4210 & 576,922 & 679,099 \\
\hline
\end{tabular}

To estimate the broker population, the average number of brokers per legislator is multiplied by the total number of legislative seats in the province concerned. For example, Table 6.3 shows that the average number of brokers for each provincial legislator in West Sumatra was 44.3 people. I then multiplied these with the total seats so the estimated broker population in the province was 2880 . In four provinces, it is estimated that there were around 97,657 brokers working for successful provincial legislative candidates in the 2014 elections, and 576,922 brokers for successful candidates in district legislatures. Note that this is only a calculation that includes the successful candidates. Brokers who worked for candidates who didn't get elected aren't included. Hence, in fact, the total number of brokers must have been much higher.

For the sample to be representative, I then weighted the data using the following formula:

$$
W_{i j k}=\frac{N_{i j k}}{N} / \frac{n_{i j k}}{n}
$$

in which:

$W_{i j k}=$ Weighting variable for provincial data $i$, DPRD level $j$, broker category $k$

$N_{i j k}=$ Population amount for province $i, D P R D$ level $j$, broker category $k$

$n_{i j k}=$ Sample amount for province $i, D P R D$ level $j$, broker category $k$

$N=$ Total population

$n=$ Total sample

$i=$ West Sumatra, Central Java, East Java, North Sulawesi

$j=$ DPRD I, DPRD II

$k=$ Legislators, brokers 
To determine statistical significance, a standard error value is needed. In this study, the standard error is calculated by assuming stratified random sampling: population grouped by province, office level (i.e. DPRD I and DPRD II), and respondent category (i.e. candidates and brokers), and then the sample in each stratum is selected by simple random sampling. However, the standard error of these surveys could have been larger than estimated. This is largely because, in practice, the sampling is conducted with a more complex procedure. All these sampling and statistical procedures are described further in Appendix B. Based on the available data, it can be concluded that the total number of brokers working for successful provincial and district legislative candidates in four provinces in 2014 was quite large $(674,579$ people $)$. In the 2014 legislative election, there were $62,994,652$ registered voters in these provinces. Hence, a broker-to-voting-eligible-population ratio in the four provinces was around 1 broker to 93 voters. Of course, if we include those who worked in other provinces, including those who helped unsuccessful candidates, the estimate would have been much bigger.

\subsection{Who Are the Brokers?}

My survey of a probability sample of brokers offers insight into the characteristics of brokers. In terms of gender composition, Table 6.4 clearly shows that political brokerage is a male-dominated field. Most of the brokers interviewed in four provinces are male, with higher percentages in Central Java and East Java at $92.7 \%$ and $91.4 \%$, respectively. The majority of the surveyed brokers were aged between 41 years and 55 years. The average age of brokers was 44 years (the youngest broker was 17 and the oldest 76). Candidates presumably tended to recruit middle-aged men because the middle-age period is associated with the greatest independence, esteem, prestige, and social involvement; therefore, these brokers can demand respect from both the young and the elderly in the community (Martel, 1968: 56) - a necessary condition of successful brokerage activity. The majority of the interviewed brokers (77.6\%) were Javanese due to the fact that one-half of the survey interviews were conducted in East Java and Central Java. Brokers were mostly Muslim (91\%), with only $9 \%$ of the respondents being Christian.

How do the findings place brokers with respect to the general population? To provide an apple-to-apple comparison, I use voter survey data only from East Java, Central Java, West Sumatra, and North Sulawesi. In 


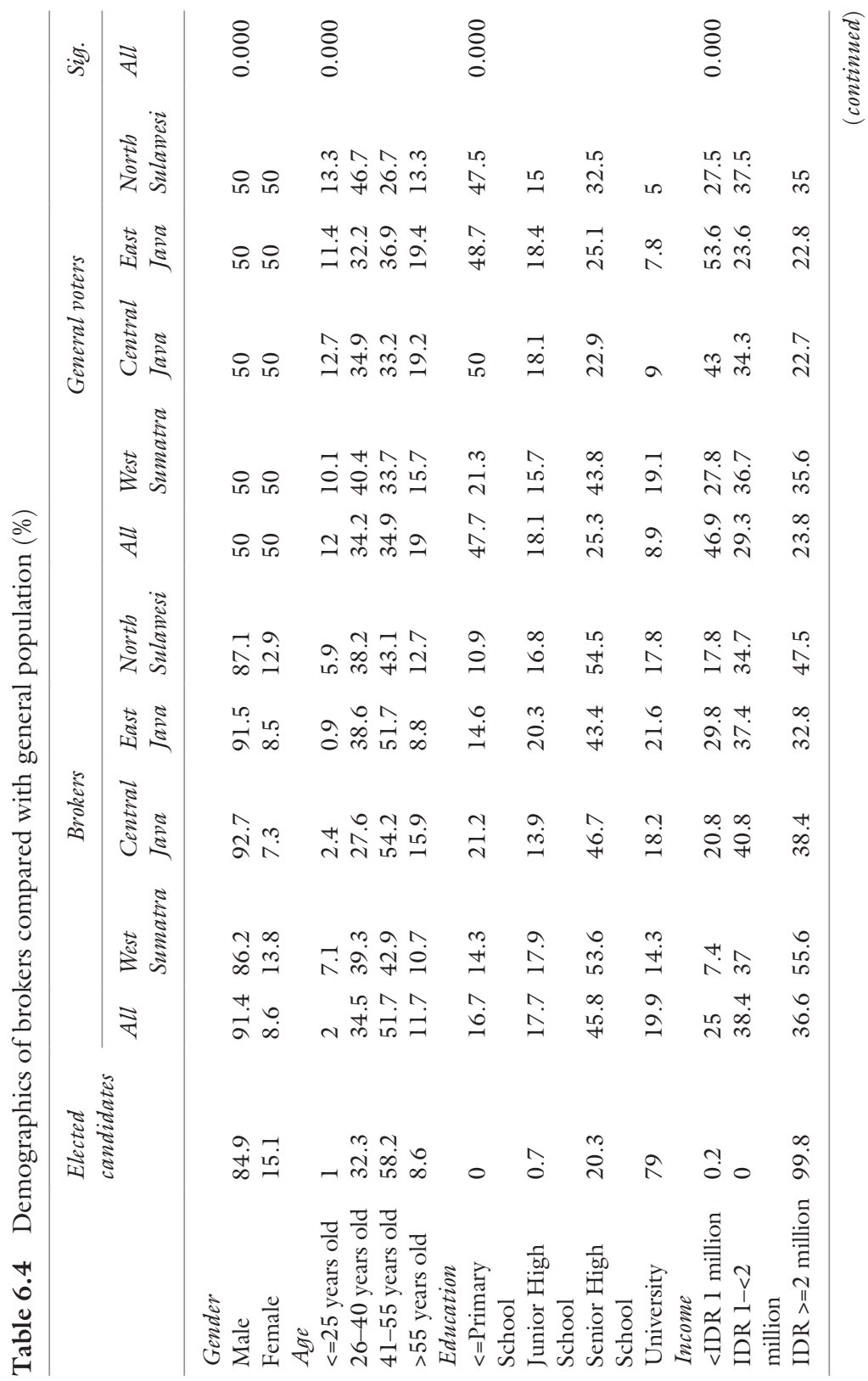




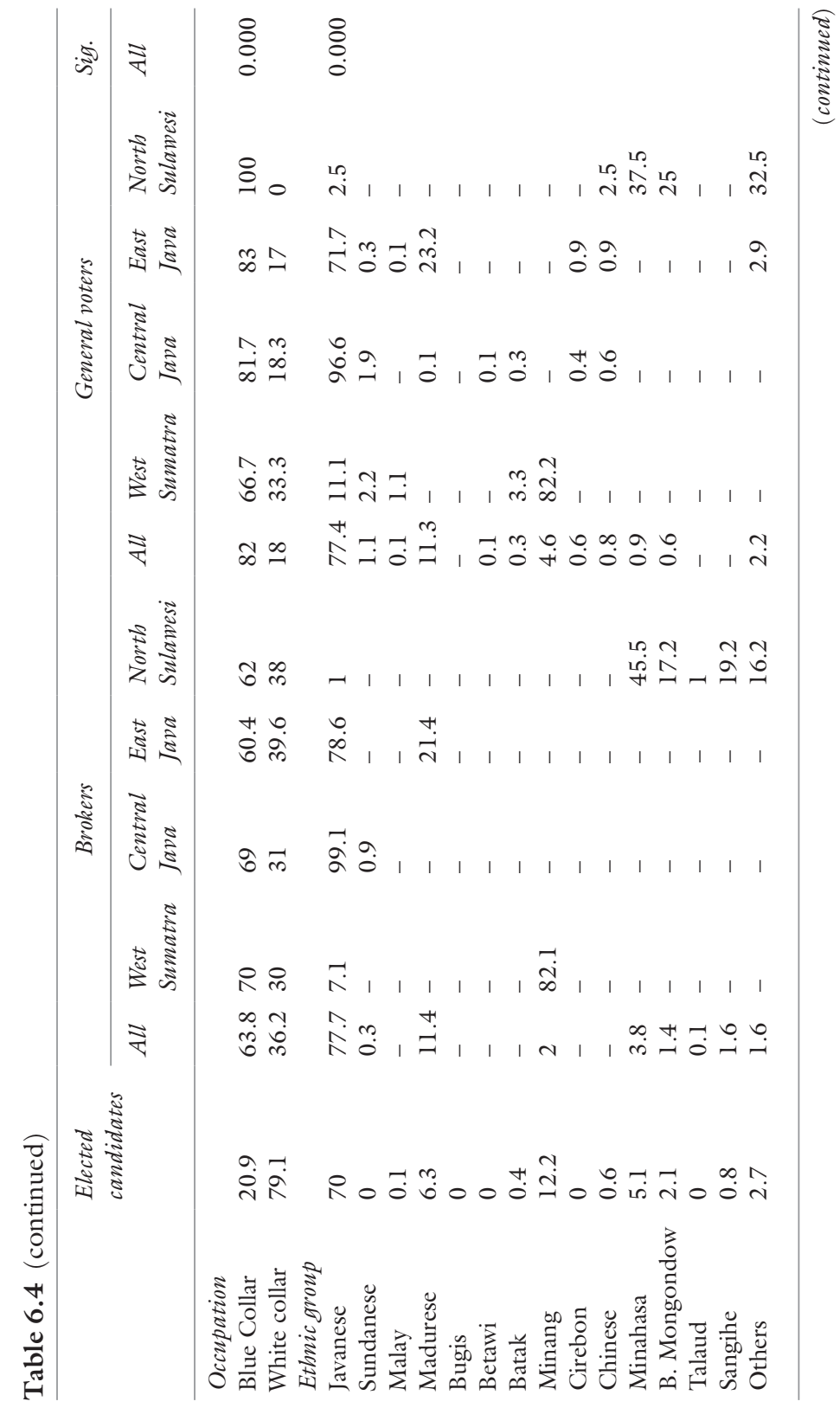




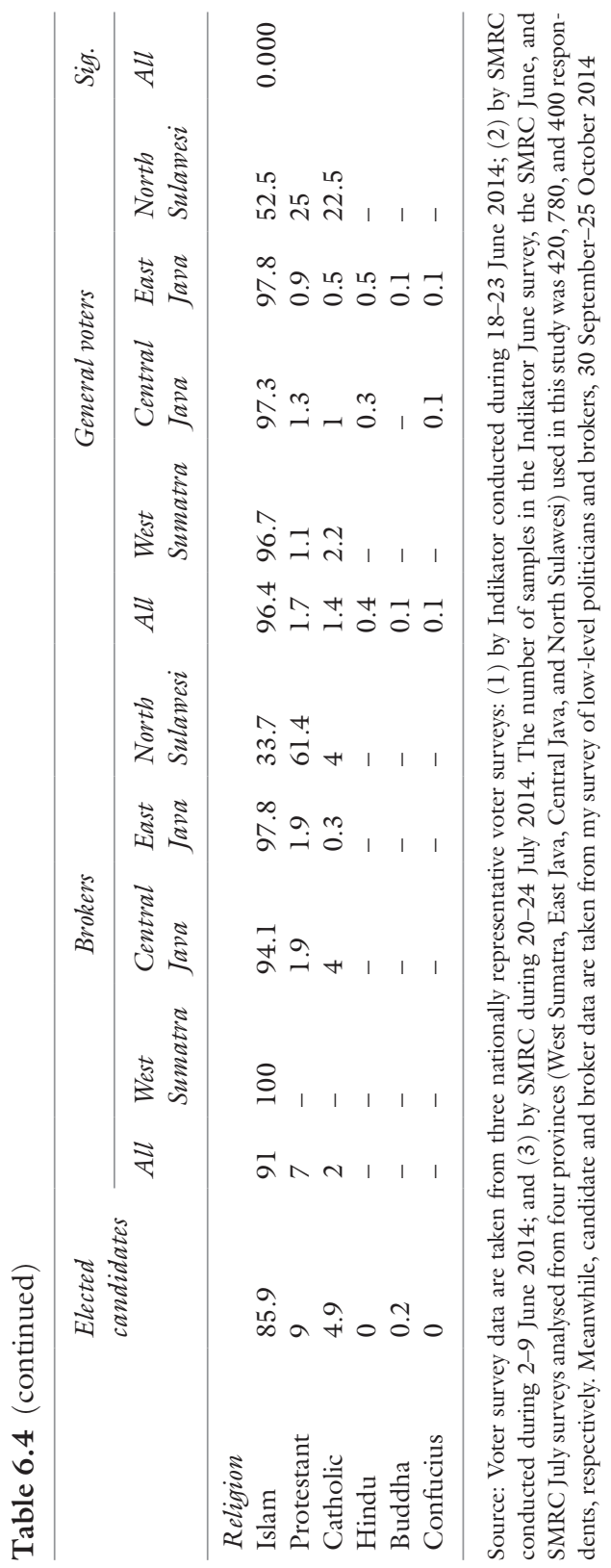


order to increase the sample size, I utilise three nationally representative voter surveys that were held simultaneously just before the broker survey was conducted (September-October 2014). In terms of socio-economic status (SES factors), my survey results reveal that, compared with voters in four provinces, brokers tended to be more educated and slightly wealthier. Table 6.4 also shows that most voters were employed in blue-collar jobs $(82 \%)$ such as farmers, fishermen, small street-stall sellers, and so on, compared with $63.8 \%$ of the sampled brokers whose jobs can be grouped as blue-collar employment. In terms of monthly earnings, surveyed brokers weren't as a group poor by Indonesian standards, though they were also not wealthy. The modal respondent earned between IDR 1 million and less than IDR 2 million per month $(38.4 \%)$, though $36.6 \%$ of brokers said their monthly income was more than IDR 2 million per month. In contrast, almost half of the voters reported monthly earnings of below IDR 1 million. Brokers were also more educated than the general population. The modal respondent in my brokers' survey was a senior high school graduate $(45.8 \%)$, though $19.9 \%$ of brokers said they were college graduates. Almost half of the sampled voters had a maximum of primary education or no education at all.

When asked whether politics was the brokers' main source of income, almost all respondents (99\%) said that politics wasn't their main profession. The largest main occupation mentioned was farmer/animal breeder/ fisherman $(26 \%)$, followed by private employee/self-employed and bluecollar worker/maid with $10 \%$ and $9 \%$, respectively. A significant number of brokers described themselves as entrepreneurs/businessmen (8\%), streetstall sellers $(7 \%)$, and teachers/lecturers $(5 \%)$. Some brokers derived income from automotive services $(4 \%)$ and wholesale trade $(3 \%)$, were retirees $(3 \%)$, or village bureaucrats $(2 \%)$. The remaining brokers were professionals (lawyers/doctors/etc.), drivers, security personnel, freelancers, or civil servants (pegawai negeri sipil, PNS).

Clearly, most of the surveyed brokers weren't full-time professional brokers; instead, brokerage was simply a temporary or part-time job at election time. This finding contrasts sharply with Zarazaga's description (2014) of everyday political mediation in Argentina, which indicates that brokers perform a wide range of roles to help their party, including performing constituency service and performing basic governmental tasks. In Indonesia, brokers are generally not multitasked in this way, but instead focus on helping their bosses to win an election. Their challenge is to combine this job with their everyday occupation. 
Table 6.5 Logistic regression of whether or not the respondent was a broker

\begin{tabular}{llc}
\hline & \multicolumn{2}{l}{ Dependent variable } \\
\cline { 2 - 3 } & \multicolumn{2}{l}{$(0=$ General voters; $1=$ Broker $)$} \\
\cline { 2 - 3 } & $\mathrm{B}$ & S.E. \\
\hline Male & $2.27^{* *}$ & 0.13 \\
Age & $0.02^{* *}$ & 0.00 \\
Income & $0.05^{* *}$ & 0.02 \\
Education & $0.26^{* *}$ & 0.02 \\
Number of organisations & $0.25^{* *}$ & 0.04 \\
Muslim & -0.05 & 0.25 \\
Javanese & 0.15 & 0.13 \\
Region (North Sulawesi) & $1.58^{* *}$ & 0.30 \\
Constant & -6.38 & 0.46 \\
Valid N & 2394 & \\
Log likelihood & 2668.1 & \\
\hline
\end{tabular}

Note: ${ }^{*} p<0.05 ;{ }^{* *} p<0.01 ;{ }^{* * *} p<0.001$

In terms of social involvement, the mean of the brokers' responses to questions asking about their involvement in various forms of associational life was 17.94 with a standard deviation of 3.68. Overall, brokers were highly socially engaged people compared with the general population. For instance, $50 \%$ of the brokers described themselves as being active members of local religious community groups (majelis taklim), which was the largest civic association mentioned, compared with $23 \%$ of the voters reported being active members of such group. ${ }^{2}$ Note that each respondent was allowed to provide multiple answers. The next most important association was rotating credit groups (arisan), with $34 \%$ of the brokers reported being active members, compared with $25 \%$ of respondents who said so in my voters' survey. Brokers were also more actively engaged than voters in some organisations such as NU, youth community councils, agricultural groups, or industrial unions and cooperatives.

To further compare the characteristics of brokers with the general population, I conducted a case-control study by combining data from my unique dataset of brokers and voter surveys (Table 6.5). In doing so, people with the outcome of interest (i.e. brokers) are compared and matched

${ }^{2}$ This is based on my post-election survey of voters in 2014 . 
with a control group (i.e. general voters). ${ }^{3}$ The assumption here is that our respondents in the voter opinion surveys weren't brokers. The results suggest that, compared with voters based on data from my polling institute's voter surveys, brokers were older, much more likely to be male, had more education, and enjoyed higher median household incomes than the typical Indonesian, and they tended to be more active in social organisations. In determining the number of selected matching variables, the region variable (North Sulawesi and otherwise) is set as a control. So this is not possible determinant of becoming a broker, given we have selected the variable from the beginning. We included the variable of region in the equation to control the variable of religion because North Sulawesi is feared to be biased for non-Muslims, while West Sumatra, East Java, and Central Java are potentially biased for Islam.

\subsection{How Do CANDidates Recruit Brokers?}

Most candidates saw broker recruitment as critical to their strategies. As one candidate of the Islamist party PPP, who ran for re-election in 2014, explained: "The last elections were all about a distribution strategy. Therefore, how we selected success team members was a key to success in securing victory" (Interview, 21 April 2014).

But what sorts of persons did candidates recruit? Generally, individuals recruited into campaign teams could be divided into two groups: party functionaries (either at the sub-district or at the village/precinct level) and non-party members (Kadir Karding, interview, 18 April 2014). Candidates felt they must involve local party functionaries in a success team, not only for practical reasons but also to avoid offending their fellow party members. Since party structures were contested by competing candidates on the party list, however, candidates couldn't rely exclusively on party cadres. Some candidates accused party functionaries of operating as 'double agents' (main dua kaki) or 'money grubbers' (mata duitan). ${ }^{4}$

In terms of non-party brokers, my broker survey provides a complete picture of how the process of recruitment works. Figure 6.1 reveals that brokerage structures take advantage of relational networks (Aspinall et al., 2015 ). Asked about their relationship with the person who asked them to join the campaign team, $79 \%$ of brokers were recruited by those they cat-

\footnotetext{
${ }^{3}$ For further discussion on case-control study, see Alan Agresti (2007).

${ }^{4} \mathrm{My}$ informants spoke on the condition of anonymity due to the sensitivity of this information.
} 


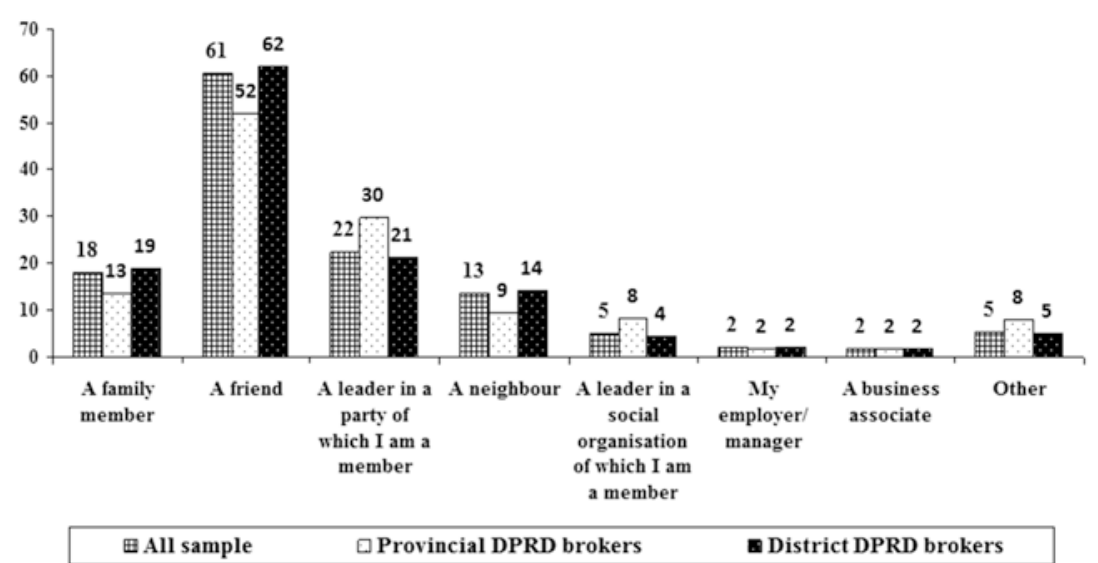

Fig. 6.1 Brokers' relationship with the person who invited them to join the team (\%). Source: My survey of brokers, 30 September-25 October 2014

egorised as family and friends. Respondents were allowed to give multiple responses, but this figure clearly indicates that candidates rarely recruited people they didn't already know well as core team members, who in turn recruited close associates, and so on down the campaign team structure. The most frequent explanation candidates gave for prioritising relational networks was that brokers with whom they were personally close were more loyal and less likely to shirk (Aspinall et al., 2015). Also, recruiting through personal networks helped to reduce the costs of maintaining a network of brokers because members would be willing to work hard on the campaign even without payment, or for lower payments than otherwise. In contrast, a modest portion of brokers were recruited by their party leaders. Interestingly, when it came to broker recruitment, candidates were more likely to favour neighbours over organisational networks, confirming that brokers were genuinely recruited on the basis of personal connections.

Consistent with earlier works, we also found evidence that most candidate-broker relationships in Indonesia were highly personalised. About $61 \%$ of brokers were asked to join by the candidate directly. This figure more than tripled the findings of a survey conducted in in Central Java III constituency by Aspinall and his collaborators (2015). Note, however, that the population of my survey was brokers who worked for candidates who were elected at provincial and regent/mayoral levels. It may be 
that candidates who constructed success teams on the basis of intimate relationships were more likely to win their seats.

Meanwhile, only 38\% of respondents were asked to join the success team by other, more senior brokers. These respondents were asked to specify the position in the campaign team structure of those who had approached them to join. The modal answer to this question was "village coordinator" (34\%), followed by "sub-district coordinator" $(30 \%)$ and "base-level brokers" (22\%). The remainder identified "regency/city coordinator" or "provincial coordinator." This parallels prior research that when candidates exhaust their supply of close friends and family members when forming a success team, they typically turn to campaign coordinators to recruit the rest. Unavoidably, among those recruited in this way, a considerable portion have connections that are more transactional than personal (Aspinall, 2014; Aspinall et al., 2015).

In short, the pattern of relationship between candidates and brokers reflects a centrality of personal networks and, by extension, relatively marginal role of political parties, in grassroots campaigns in legislative elections. Asked whether they knew anything in advance about the candidate they supported, $71 \%$ of brokers knew the candidate personally and were close to him/her. Around 19\% knew the candidate personally but weren't particularly close before becoming part of the campaign team. Only $4 \%$ had heard about the candidate but never met him/her; $5 \%$ had never heard of the candidate before. Again, recall that the sampled brokers were those working for elected candidates. Prior contacts between candidates and brokers partly mediate electoral success. Many candidates failed to be elected presumably because they used a much looser method of selecting brokers without ensuring whether or not they were truly committed to them.

Such prior contacts, however, don't necessarily imply long-term clientelist interactions. Some brokers might have personal affective ties to the candidate, without clientelist exchanges. Respondents were asked to name whether they had had prior assistance from a number of actors such as the candidate, success team village coordinators, sub-district coordinators, district coordinators, and party leaders. Although $71 \%$ of brokers knew the candidate personally prior to becoming a member of his/her success teams, the left panel of Fig. 6.2 shows that only $37 \%$ had previously received assistance from the candidate or team members. As a follow-up, these $37 \%$ of brokers were requested to specify the forms of assistance they 


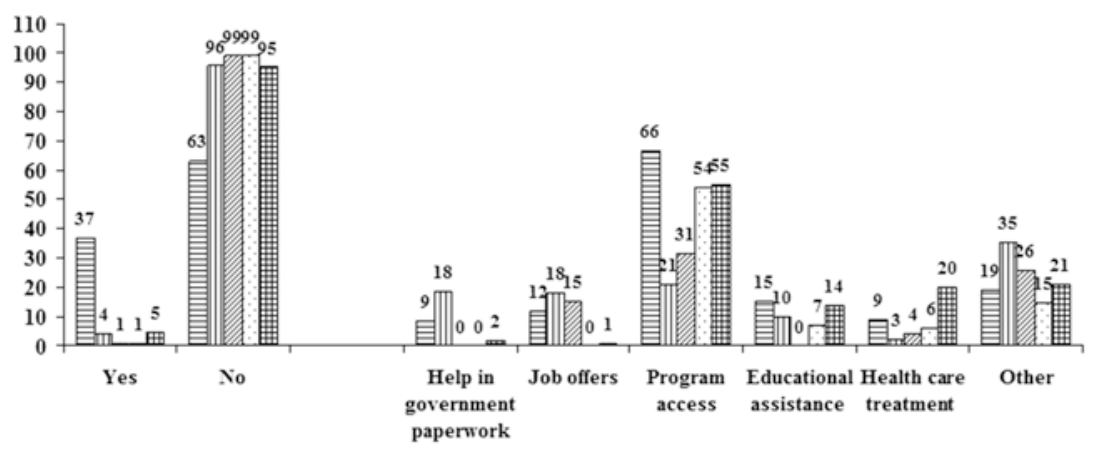

目 Candidate $\square$ Village Coordinator $\square$ Sub-district Coordinator $\square$ District Coordinator $⿴ 囗 十$ Party Structure

Fig. 6.2 Prior mutually beneficial exchanges involving brokers (\%). The question in the left panel reads: "Before becoming a success team member, have you ever received assistance (e.g. in government paperwork, job assistance, project access, schools, health care treatment for you or family members), from the following parties?" If "Yes," the interviewer asked a follow-up question: "In what forms? (Can be more than one answer)." The responses to this question are then shown in the right panel. Source: My survey of brokers, 30 September-25 October 2014

had received. As shown in the right panel of Fig. 6.2, the modal answer was 'project access' $(66 \%)$, such as constituent funds for the construction of roads, bridges, and so on.

Clearly, distribution of such patronage helps create networks for the candidate (see Chap. 5). It gives incumbent candidates a comparative advantage in getting re-elected since they have had the opportunity to form patronage-based networks since at least the preceding election and have greater access to pork-barrel projects and other state resources while sitting in the legislature. Numerous brokers had also received educational help (15\%), job offers (12\%), health-related assistance (9\%), and help in government paperwork $(9 \%)$. The proportion of those who said they had received other forms of help, such as money, goods, or protection, was also numerically significant (19\%). Meanwhile, 63\% of brokers hadn't received help from the candidate. These respondents mostly were located at the ground level and didn't work directly with the candidate. They interacted directly with voters instead. I call them 'extended success teams'-people who are recruited by the senior brokers who usually enjoy 
direct access to the candidate. As explored in the following section, these extended success teams are a source of rent-seeking because brokers at this level often have transactional rather than personal commitments to the candidate.

However, an important point is that the left panel of Fig. 6.2 demonstrates that brokers seem to be more tightly bound to candidates than with other actors when it comes to clientelist exchanges. Only a tiny fraction of brokers had had prior clientelist interactions with more senior brokers. Of those, only an insignificant number had benefited from party leaders, confirming that the relationship between candidates and brokers is more personal than partisan. The results show evidence of the weakness of clientelist ties between party structures and brokers. Likewise, very few respondents mentioned their prior exchanges with campaign coordinators at the district level (1\%), sub-district level (1\%), and village level (4\%). All of this suggests that the nature of the relationship between ground-level brokers and coordinators at district or sub-district level is generally one-off, noniterative, and short term. The relationships between candidates and at least senior brokers, however, tend to be more personal and long lasting.

\subsection{What Are Brokers Looking for in a Candidate?}

The dominant literature on clientelism suggests that an individual's motivation to join a broker network is primarily driven by partisan orientations (e.g. Auyero, 2001; Zarazaga, 2014). The scholarly focus on the role of political parties and party brokers has left the function of individual candidates and their non-party brokerage networks relatively understudied. But in a context like Indonesia, where parties play a minor role in grassroots campaigning, and where under the open-list PR system co-partisans compete against each other, why should a broker end up working with one candidate rather than another? One answer is that brokers vary by types depending on the differing commitment and the degree of personal closeness to the candidate. Some are "pragmatists," in Szwarcberg's (2015: 2) term, or "opportunists" in Aspinall's (2014: 545) categorisation who seek immediate payoffs during the course of a campaign, and will thus gravitate towards whichever candidate offers the best material payoffs. Others are "clientelist brokers," in Aspinall's term, who intend to have durable relations with the candidate in the hope of receiving future benefits (2014: 545).

My own findings suggest, first and foremost, that a candidate's personal reputation is important in attracting brokers to a success team. Figure 6.3 


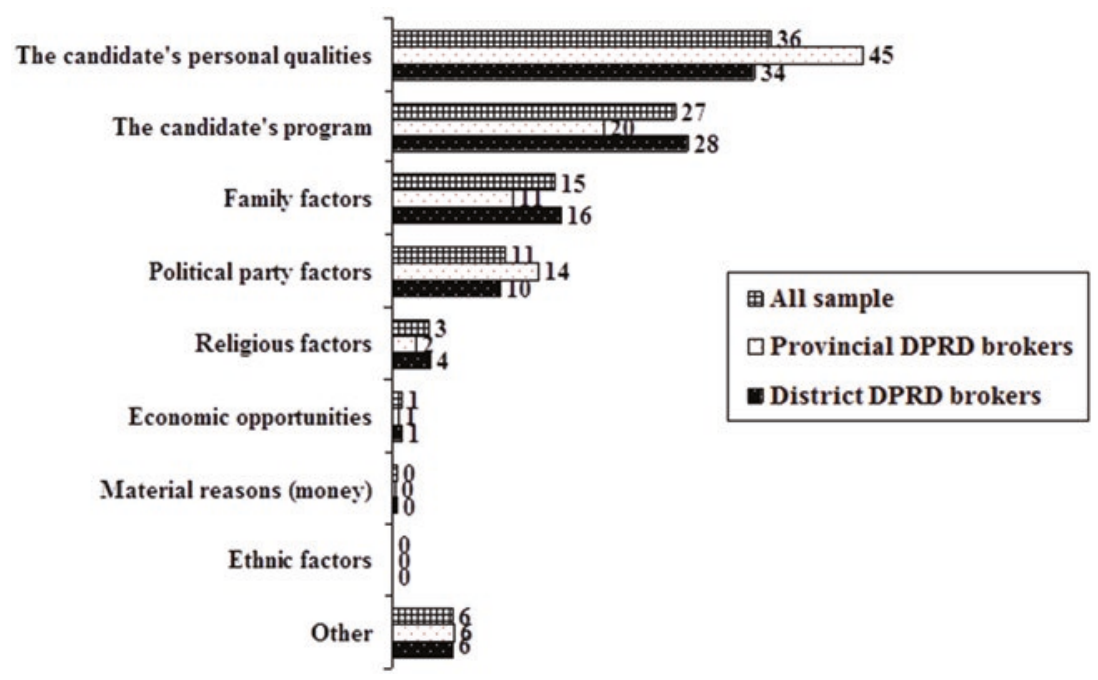

Fig. 6.3 Reasons for joining a candidate's success team (\%). Source: My survey of brokers, 30 September-25 October 2014

illustrates the main reason respondents gave for joining a success teamwith the important caveat that the sampled brokers here all worked with successful candidates. Few depicted themselves as pragmatist brokers whose materialistic motivations are typically blamed for the failures of success teams to reach expected vote targets. Only an insignificant number were primarily motivated by ethnic and religious factors. The primary motivations success team members gave were the 'candidate's ketokohan' (personality or personal qualities) and the 'candidate's programmes.' These responses point to the significance of personal reputation in generating electoral support independent of the party. This finding corresponds with the dominant discourse among candidates and brokers in interviews during my 13-month fieldwork in Indonesia. They sometimes used the word figur, which is more or less synonymous with ketokohan, to illustrate that it was the candidate's individual qualities that really mattered under the open-list PR system.

Virtually all brokers admitted that a candidate's personal reputation helped increase his or her vote share. My very large dataset surveys of voters in 73 electoral districts across Indonesia also reveal that, when asked to name the personal qualities they think are most important in a candidate, 
the majority of respondents named "honest/trustworthy" and "cares for the people." In Indonesian politics, caring for the people connotes having a track record of having delivered benefits or patronage to voters. Similarly, the term 'programme' as in Fig. 6.3, has a specific meaning in the Indonesian context, as Aspinall et al. (2015: 12) explain:

It refers not to a collection of policies or ideas the candidate supports-what we might elsewhere call a candidate's platform - but to what a candidate has done for the village/voters/constituency. In other words, "program" refers to how adept or generous the candidate has been in providing the area with pork, patronage, and club goods.

Candidates who are able to meet those desirable criteria come to be viewed as having higher prospects of victory. Other things being equal, brokers prefer "to work for a candidate who was likely to win rather than one who was personally wealthy but had poorer prospects of victory" (Aspinall et al., 2015: 12). This statement nicely parallels my interviews with brokers: when they decided to work for a candidate, it had little to do with whether the candidate was using a vote-buying strategy, and much more to do with the candidate's reputation, since a strong reputation would maximise chances of victory. This isn't to say, of course, that personal reputation is itself sufficient to obviate the need to distribute cash to voters; even many candidates with strong records of patronage delivery and personal popularity in their electoral districts felt that they still needed to use vote-buying strategies in order to lock in the support of their voters.

\subsection{Whom Do Brokers Target and How?}

What structures do politicians construct to engage in vote buying? The typical organisations of brokers, which are known locally as tim sukses (success teams), work within a pyramidal and territorial structure. At the apex of a typical success team for a DPR member is an inner circle of two or three people who help build and control the network. As observed by Aspinall (2014), the bulk of the structure consists of a territorially organised network, stretching down to the village and, often, hamlet or even polling booth level, where local brokers are recruited to directly influence voters (Aspinall and Sukmajati, 2016). Hence, the majority of success team members consist of base-level brokers-what I called the extended success team-whose local networks allow them to collect votes on the candidate's behalf. These base-level brokers play a critical role since they have to pro- 
vide lists of voters willing to vote for the candidate, deliver the payments to them, and then monitor the recipients to ensure they show up on voting day.

In terms of targeting strategies, it is clear that when it comes to determining who gets targeted for vote buying, brokers predominantly rely on personal networks or simply on personal closeness to brokerage networks. As shown in Fig. 6.4, brokers usually target people among their family members, neighbours, friends, and relatives in the village. Although brokers have an incentive to expand electoral support beyond their personal networks, they tend to favour easy targets to increase the effectiveness of vote buying and reduce the cost. When asked to name multiple targets, a modest portion of brokers also mentioned those who were active in their professional and religious community groups. When asked to specify where their vote targets lived, most of them said they resided in the same neighbourhood or village (Fig. 6.5). There was little variation between provinces, indicating that the targeting strategy based on brokers' personal networks is likely common across Indonesia.

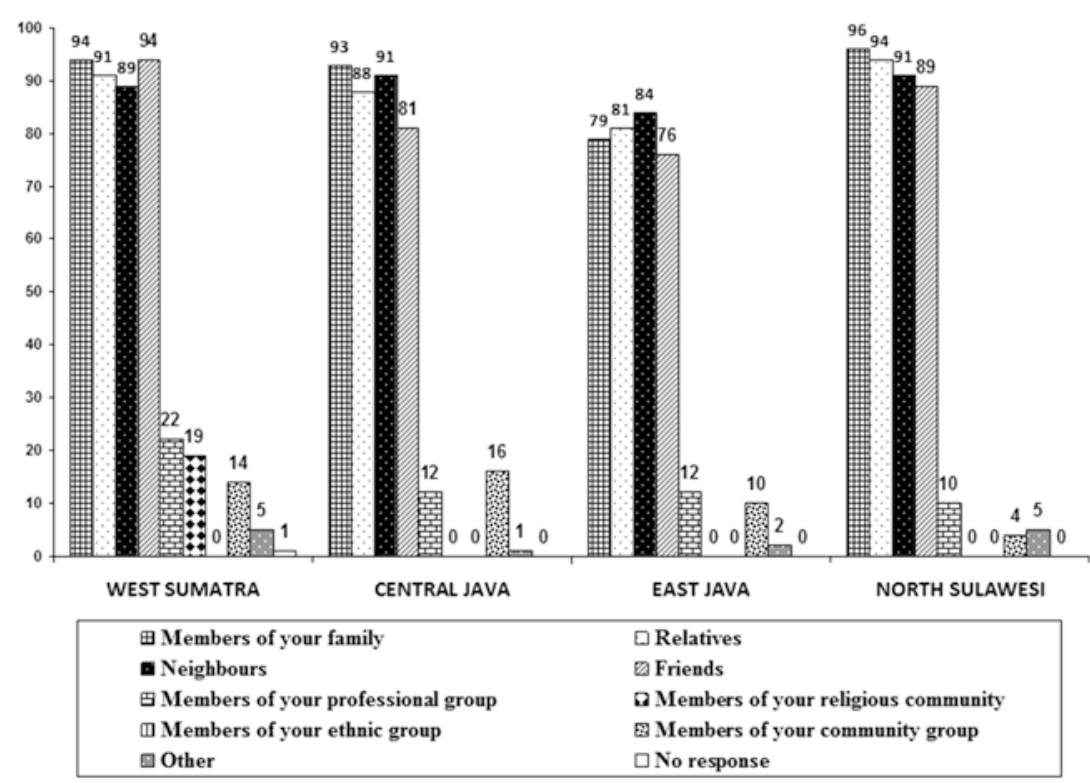

Fig. 6.4 Who did brokers ask to vote for the candidate they support? (\%). Source: My survey of brokers, 30 September-25 October 2014 


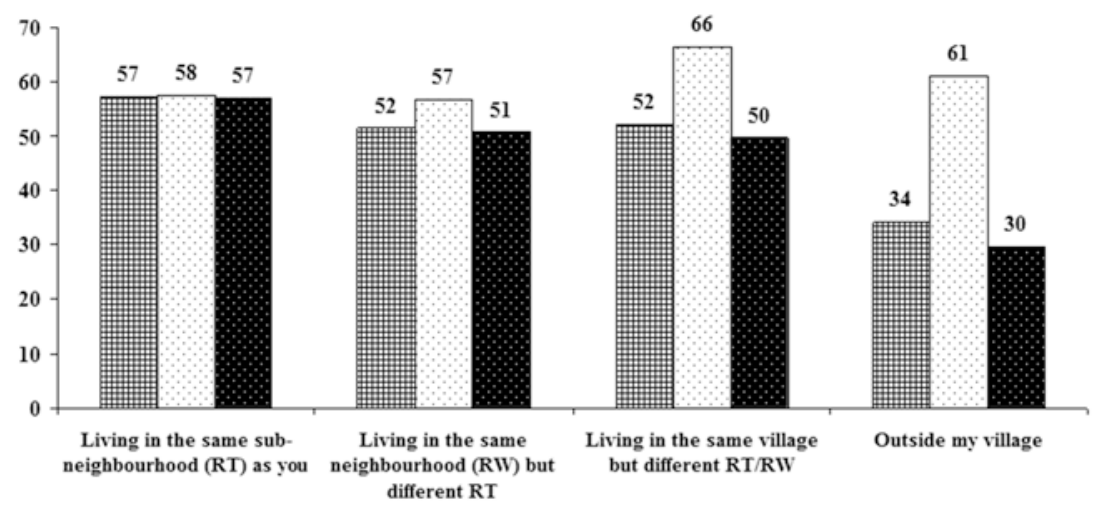

田 All sample

$\square$ Provincial DPRD brokers

District DPRD brokers

Fig. 6.5 Where do the people targeted by brokers live? (\%). Source: My survey of brokers, 30 September-25 October 2014

A parallel discourse emerged from my qualitative findings, suggesting that most brokers chose to prioritise voters whom they know and who know them. However, the number of such voters was limited. Recall that when brokers often talked about family, they didn't only refer to their immediate kin but much wider ties, linked to them via kinship or common ancestors, marriage connections, emotional relationships, and place of birth or residence (Alamsyah, 2016: 108). In my interviews with many brokers, I asked why they favoured such a personal strategy. The most frequent answer was that such persons were the most reliable voters. By directing benefits to their personal networks, they believed their offers wouldn't go to waste. In fact, as long as the personal connections between brokers and voters were strong, the payment was simply often just a courtesy. There is a shame effect if the targeted family members and close associates accept the offer but don't reciprocate with votes. One broker working for a candidate running in an electoral district in East Java said, “The point isn't how much money did you give but who gave the money to voters. Voters in the villages don't care about politics," (Interview, 30 September 2014). Another broker, whose wife was running for a district parliament seat in South Tangerang, put it, "They even don't know which candidate I support" (Syafrani, Interview, 5 December 2014). The broker wasn't only an influential leader in the district but also one of the leading commentators on law and politics, appearing on prime-time television programmes several times a week. 
All of this suggests that it isn't the message but the messenger that matters. As one broker put it, "The more brokers a candidate has, and the greater family and friendship networks a broker has, the bigger chance for a candidate to win" (Interview, 4 October 2014). My low-level politician survey found that the number of brokers working for the sampled candidates, who were successfully (re)-elected in 2014, varied in size, including one extreme outlier-one candidate reported working with 3000 brokers. But the mean number of brokers was 149.44 with a standard deviation of 299.1, suggesting that team sizes were quite large. Faizin, a successful candidate from the Islamist party PPP who ran in 2014 for a district parliamentary seat in Batang, Central Java, explains:

For the candidates, rather than assigning brokers to collect a significant number of votes ... beyond their limits, it is better to have a bigger army of brokers but ask every one of them to chase fairly modest vote targets. If you burden your brokers with impractical tasks, they will certainly fall short of expectations. (Interview, 23 January 2017)

In other words, if the target is set too high, it will be difficult for brokers to reach it due to the limits in the number of family-and-friend votes they can access. But since most candidates need to chase a large number of votes, brokers in fact often do exhaust the support of those with close personal connections to them. Inevitably, they must reach out to those with whom they lack close personal ties, increasing the risk of wastage and slippage. The longer the list a broker collected, the more likely it would include voters beyond his/her immediate circle, which then increases the prospect of a higher failure rate.

\subsection{How Do Brokers Determine What, When, And How Much to Give?}

It is technically difficult to distribute benefits to a large number of voters when time is running short, as it inevitably does towards the end of a campaign period. Part of the solution is that candidates favoured distributing cash over staple foods because it is extremely difficult to procure and distribute food in a context where vote buying is illegal. The results from the brokers' survey show that they were three times more likely to report handing out cash (16\%) than foodstuffs (5\%), which is consistent with our voter survey results. Designed as a multiple choice question, the most common item offered to those who self-reported vote-buying attempts $(25.1 \%)$ was money $(75.5 \%$ of $25.1 \%=18.7 \%)$; foodstuffs $(12.8 \%)$ such as 
rice, sugar, or noodles; and household items such as kitchenware or crockery, or religious clothes like headscarves, prayer robes, or mats (11.4\%). Some respondents also mentioned other items such as clothing, cigarettes, health and death insurance, medicine, and so on.

This study did find substantial heterogeneity by province where the proportion of brokers reporting engagement in distributing cash was $22 \%$ in Central Java, 14\% in East Java, 8\% in North Sulawesi, and only 4\% in West Sumatra. This closely mirrors the data from my voters' surveys suggesting that vote buying has become an endemic problem in Central and East Java but is much less common, especially, in West Sumatra. We must also assume a significant social desirability bias, leading to some underreporting of engagement in vote buying, in each province.

The literature on clientelism has long stated the effect of constituency size on the relative costs and effectiveness of vote buying. Scholars argue that a small constituency size may increase the likelihood of vote buying (Stokes, 2007: 86-87; Hicken, 2007: 56-57). However, my broker survey shows that constituency size doesn't seem to have much effect ${ }^{5}$; in fact, $24 \%$ of provincial brokers reported they engaged in vote buying, while only $20 \%$ of district brokers said so, though this difference wasn't statistically significant. At least this suggests that vote-buying efforts didn't only take place in small electorates but also happened in larger electorates. When it comes to the amounts of money distributed, there was significant variation, including inter-regional variations. For instance, candidates spent lesser sums per voter in Java than in the two outer island provinces. In many instances, it is more expensive to 'buy' urban dwellers than rural residents. To some extent, there are also inter-candidate variations. In some areas, wealthy candidates set the price of a vote much higher than the market price ( harga pasaran) of a vote (Aspinall et al., 2017: 5).

Overall, however, when it comes to the amount of cash distributed to voters, the effect of constituency size really mattered. Figure 6.6 illustrates the pattern. Brokers working with provincial candidates usually distributed smaller sums of money (typically below IDR 25,000 per voter) than district-level brokers. It shows those who gave out larger sums, from IDR 30,000 to IDR 50,000 to be exact, were more likely to be district-

\footnotetext{
${ }^{5}$ This finding isn't necessarily inconsistent with the constituency size argument, however. It isn't the number of voters that matters, but rather, votes/seats, or the number of votes needed to win. If the number of seats grows as the number of voters grows, then there is no change in the size of the constituency.
} 


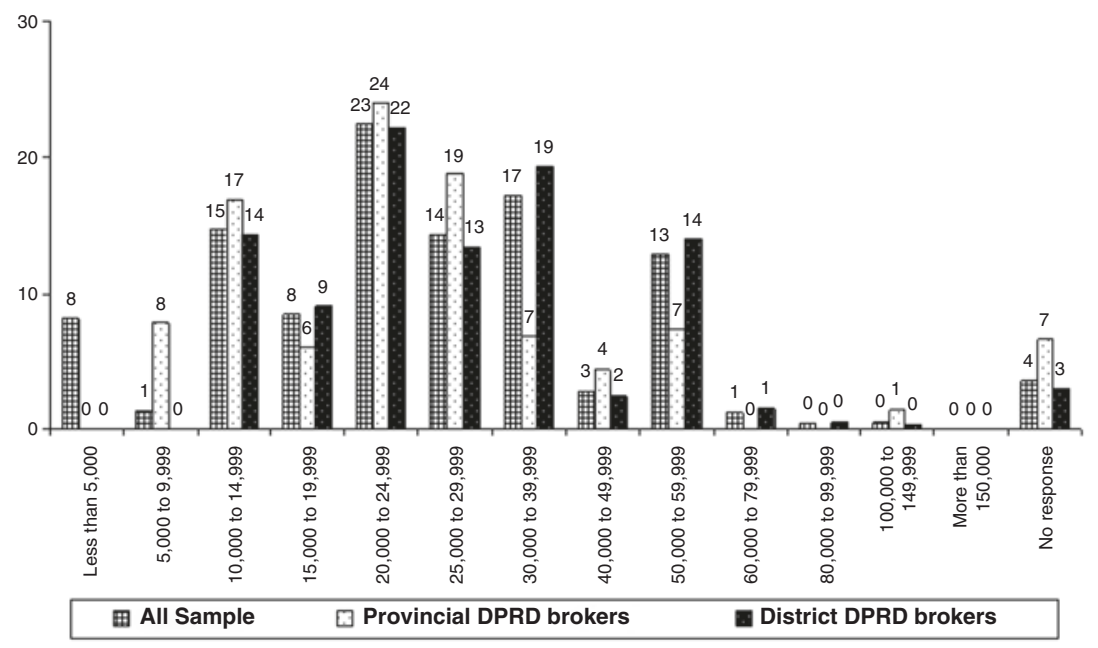

Fig. 6.6 How much money did brokers distribute to voters? (\%). Source: My survey of brokers, 30 September-25 October 2014

candidate brokers than provincial brokers. Through interviews with candidates running for the DPR, I ascertained that they mostly gave out even smaller payments than did candidates for the provincial DPRD I seats. Albeit with significant variations in the amounts paid, they generally distributed smaller cash handouts that ranged between IDR 10,000 and IDR 15,000 per voter. The reason is simple: candidates running for national-level seats had to collect many more votes than did candidates for the provincial-level parliaments. ${ }^{6}$ Candidates contesting for national DPR seats had to win hundreds of thousands of votes to secure victory, while those running for provincial DPRDs usually had to secure tens of thousands of votes. Similarly, candidates for district-level legislature had to provide much larger payments because they had to secure only 2000-10,000 votes.

In sum, the total expenditure on vote buying of national and provincial candidates was still more costly than that of district candidates. A successful national candidate from the traditionalist Islamic party running from one constituency in Central Java admitted distributing 450,000 envelopes containing sums of between IDR 10,000 and IDR 20,000 each (Interview,

\footnotetext{
${ }^{6}$ However, this is not the case in Java where the boundaries of the national and provincial electoral districts coincide (Aspinall and Sukmajati, 2016: 15).
} 
20 April 2014). If the average price of the vote was IDR 15,000, the candidate spent IDR 6.75 billion on vote buying. A re-elected candidate, from PAN, admitted that running in the 2014 elections was extremely expensive. He said, "I ran three times in the elections, but the 2014 campaign was the most 'brutal' one" (Interview, 22 April 2014). He was visibly emotional and appeared to tear up when recalling his brother's crying during his campaign because he felt guilty for his inability to help support him financially, instead assisting him only through his prayers.

Given there are overlapping constituencies in Indonesian legislative elections, politicians reduce the costs associated with the larger electorates by coordinating their efforts through cooperative deals, which are usually called 'tandem arrangements' with other candidates. My unique survey of candidates shows that provincial candidates were more likely to run in a tandem pair with a DPR candidate than with district candidates. About $55 \%$ of the sampled district candidates reported collaborating in a tandem with provincial candidates, while $73 \%$ of the surveyed provincial candidates ran in a tandem pair with district candidates. The data show that provincial candidates were more likely to have such cooperation than district candidates. Almost all of these tandem arrangements occurred within a single party. In terms of vote-buying expenses, DPR candidates usually shared funding with lower-level candidates who were more responsible for providing personnel to conduct the transactions on behalf of either lowerlevel themselves or the DPR candidate. In my interviews with DPR candidates, they were concerned about the reliability of their local counterparts in handing out cash on their behalf. It was often the case that tandem arrangements benefitted only the local candidates, who used the extra money that came to them from the DPR candidate to increase the amounts distributed to each voter without acknowledging their higher-level counterpart.

Figure 6.7 provides insights into the timing of cash distribution. Using a disguised technique to reduce social desirability bias, I asked the respondent to observe how many brokers from the same village as him/her distributed cash to voters. As the top panel of Fig. 6.7 shows, a plurality of provincial brokers said that payments were made in the final 24 hours leading up to the vote. In contrast, district brokers seem to have no specific time frame in mind for handing out cash (bottom panel), suggesting that vote buying can occur at any time even before the 'quiet period' that begins three days before the vote when no campaigning is permitted. The modal answer is "the night before voting day," which is consistent with 

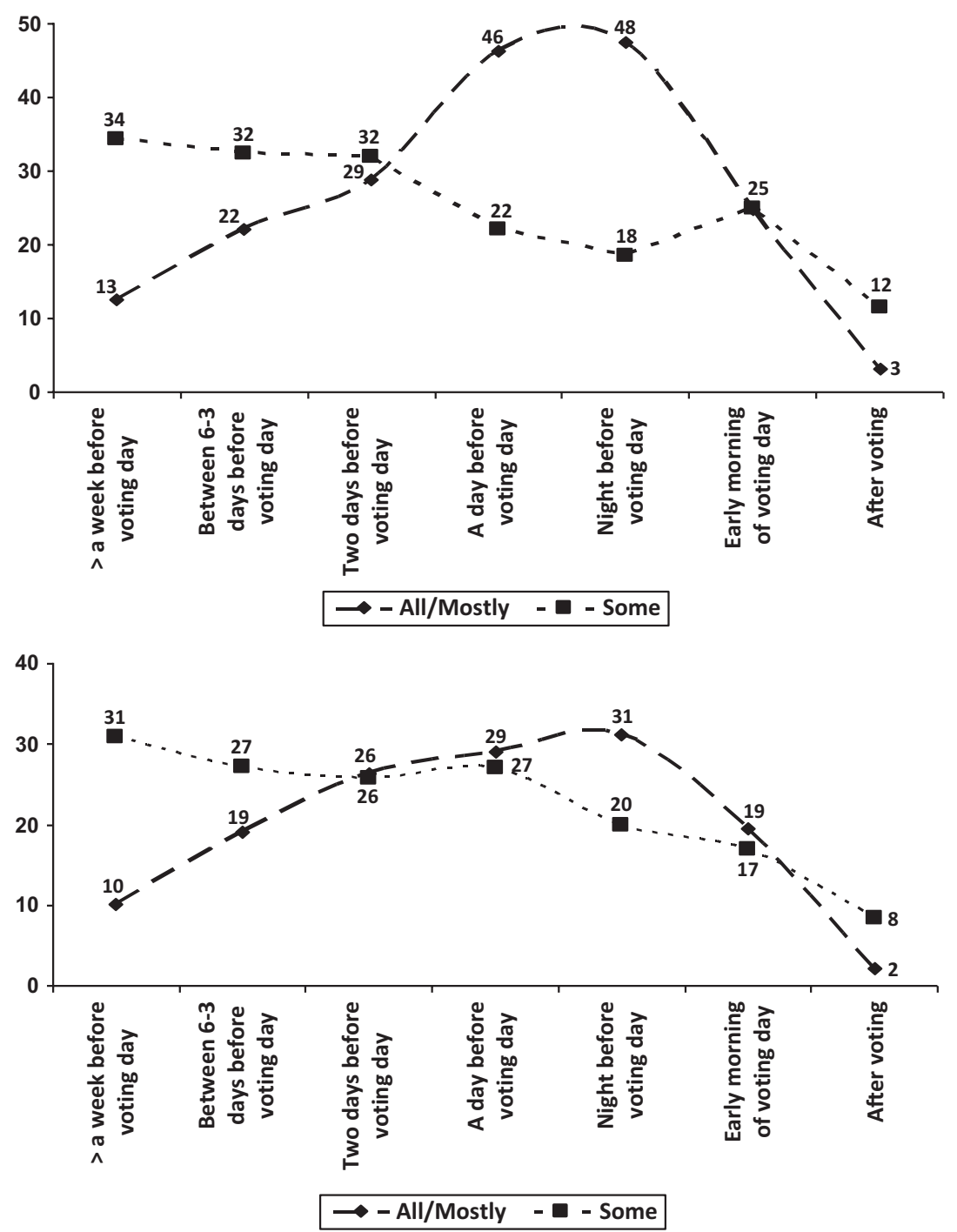

Fig. 6.7 When did provincial brokers (top panel) and district brokers (bottom panel) hand out cash to voters? (\%). Source: My survey of brokers, 30 September-25 October 2014 
the conventional wisdom, but this option only had a razor-thin lead. It is a widely held view among candidates and brokers that voters will often vote for the candidate who distributes payment closest to the vote, as the final payment is considered to have a greater impact in voters' memories (a point I return to in a moment). But why was this not the case for district candidates?

Because they occur in smaller constituencies, the intensity of vote buying is greater in the district-level DPRD contests, where candidates can secure a seat with only a few thousand votes. The smaller constituency size allows candidates and their political operatives to gain knowledge about their rivals' tactics. When they learn that rival teams have begun distributing cash, they are typically provoked to follow suit. As argued in Chap. 5, candidates often feel anxious that their supporters will desert them in favour of cashed up rivals, if their loyalty isn't secured by way of a payment. In contrast, in the larger provincial constituencies, it is more difficult to keep tabs on competitors. Overall, however, the big picture remains unchanged: as the elections draw near, the probability of vote buying increases, as I will elaborate in a more detail in Chap. 7. Interestingly, as shown in both the top panel and bottom panel of Fig. 6.7, post-electoral payoffs aren't common in Indonesian elections. This corresponds with the widespread perception among brokers who believed that the majority of voters would vote for the candidate who distribute cash last-just before polling stations are open, so that distributing handouts after the election is wasteful.

\subsection{How Do Brokers Extract Rents?}

From the outset, I have stated that my explanation of vote-buying patterns in Indonesia, which integrates attention to a party-loyalist strategy with emphasis on personal networks, points to a style of vote buying that is prone to rent-seeking behaviour. My study is consistent with the growing interest in the literature on the issues of broker predation and defection (e.g. Aspinall, 2014; Stokes et al., 2013). In my interviews and FGDs with candidates, they raised deep concerns about the unreliability of brokers, especially those who didn't enjoy prior relationships with them. Confronted by the risk of embezzlement and defection by their brokers, candidates therefore constructed their personal campaigns on the basis of relational and personal networks in order to minimise brokers' misbehaviour. As noted earlier in the chapter, however, due to the limited availability of brokers who have personal ties to the candidate, most ended up 
building 'extended success teams' involving at least some persons with no direct personal relationships with the candidate. Drawing from my unique dataset of brokers and candidates and close analysis of campaigns during the 2014 elections, I find at least five pieces of empirical evidence pointing towards agency loss $^{7}$ - which implies that brokers can extract rents from candidates - and broker unreliability.

First, this study found significant evidence of brokers' misbehaviour, especially defection, or at least the potential for it. Overall, $28 \%$ of brokers in my survey admitted they were asked to support multiple candidates during the 2014 election. Provincial brokers were more likely to be approached by multiple candidates, especially from the same party. Among those being targeted by multiple candidates, 39\% were approached by candidates coming from a different party. Interestingly, district brokers were more likely to be asked by multiple candidates from different parties. The survey also asked: "Were those candidates competing at the same legislative level (DPR RI, DPRD I, DPRD II) or a different level?" The modal answer is "different legislative level" $(61 \%)$, which potentially suggests that even if they ended up working for more than one candidate, they may not have been in direct competition for the same votes. However, 29\% of brokers were asked by multiple candidates who competed at the same legislative level and in the same electoral district and were therefore in direct competition. The remaining $8 \%$ were at the same legislative level but in different electoral districts. Evidently, district brokers were more likely to be targeted for defection than provincial brokers. There were hundreds of thousands of candidates running for seats in district-level legislatures, simultaneously trying to draw on the same supply of brokers, creating incentives for opportunistic brokers to defect or to split their efforts between more than one candidate.

Second, as implied by the territorially pyramidal structure of success teams used by most candidates (Aspinall, 2014), it is possible that "some of the money they were distributing would go missing, as it had to be passed through several sets of hands... before it reached the voter" (Rohman, 2016: 243). While considering social desirability that might lead brokers to underestimate rent-seeking, this study used an obtrusive measure: "Did you receive any envelopes/cash to distribute to voters from

${ }^{7}$ Chap. 5 conceptually discusses agency problems in the relationships between candidates and brokers and the interactions between brokers and voters in which both problems bring costs to candidates. 
the candidate or campaign coordinator?" About 16\% said yes; of those, $12 \%$ reported diverting resources for their personal benefit. Only $5 \%$ of brokers reported receiving staple goods to be distributed to voters; of those, $11 \%$ expropriated these in-kind goods. The actual cases may well exceed those figures, but these figures show that the widely held assumption that many brokers engage in extracting rents is well founded. ${ }^{8}$

Third, I did find a consistent pattern in the dataset showing that brokers have an interest in exaggerating the number of supposedly base voters and even in deceiving their candidates on this issue (see Chap. 5). The survey asked: "In your opinion, are you certain that your neighbours' swinging voting intention can be directed according to campaign team's persuasion if given assistance (envelope/money/gifts, construction of houses of worship, irrigation, roads, etc.)?" Nearly $70 \%$ of brokers claimed that they were "very" or "quite certain" they could influence their neighbours' voting decisions by giving them material inducements. However, this response might not simply be a measure of the susceptibility of voters to patronage but also a reflection of rent-seeking behaviour on the part of brokers. When brokers provide high estimates of the effectiveness of their gifts, the more cash they will have to distribute, and the more they can engage in predation. By promoting this expectation, brokers are sending a message to candidates to provide more benefits for them to distribute.

The issue here is that though brokers express confidence in their ability to sway voters with gifts, research on voters themselves provides little evidence to support this view. Recall that in my post-election survey of voters, respondents were asked to assess whether vote buying was acceptable or unacceptable. Among those who thought it was acceptable (40\%), a follow-up question was provided: "Will you accept those money or gifts?" The modal answer was that they would take the money but vote based upon their conscience $(57.7 \%)$, while some answered they would 'not accept.' This evidence confirms the classic problem of vote buying being an uncertain business. Funneling benefits to uncommitted voters is a risky bet because they can behave opportunistically (Diaz-Cayeros et al., 2012: 77). Asked what they would do with voters who received payments but

\footnotetext{
${ }^{8}$ Indeed, we found quite a small number of brokers admitting rent-seeking behaviours. Note that the population of my survey was brokers who worked for successful candidates who, as discussed above, mostly had had clientelist interactions with them. While acknowledging social desirability bias, it may be that candidates who built success teams on the basis of personal and long-lasting relationships were more likely to win because their brokers were less likely to extract rents.
} 
didn't come to the voting booth, 73\% of brokers said they wouldn't do anything. Why, then, did brokers insist on directing benefits to such voters when they couldn't guarantee that the recipients would reciprocate on voting day? By urging their candidates to distribute money or gifts to uncommitted voters, brokers had greater opportunities to extract rents.

Fourth, another common example of shirking was that the candidates' claims that most brokers worked on the basis of systematic voter lists proved to be unfounded. Most candidates say that they instruct groundlevel brokers to draw up lists of potential voters willing to support them, a process known locally by the English-language term, 'by name, by address.' Some candidates I encountered even showed me a stack of their brokers' voter lists. However, it turns out that success team members who compiled voter lists weren't as numerous as candidates expected. Only $47 \%$ of provincial brokers admitted that they drew up voter lists and $52 \%$ of district brokers did so. If it is the case that most candidates had these lists, why did only about half the brokers reportedly produce them? A candidate from PAN admitted that many candidates were tricked by their brokers, who provided them with fake voter lists. Accordingly, he always quality controlled the lists by conducting spot-checking, hiring a polling firm for this task, and finding that some people whose names were on the lists were already dead (Interview, 22 April 2014). It is also plausible that some brokers worked for multiple candidates at the same time, giving them exactly the same voter lists (Triantini, 2016: 258).

Even among those who provided voter lists, not all of the names on the lists ended up voting for the candidate a broker supported. Some opportunistic brokers intentionally filled their lists with names of individuals whose voting behaviour couldn't be determined, simply as a way to generate profits. Recall that most candidates rely on these lists as a basis for delivering cash payments. According to Triantini (2016: 250), in the case of Blora, Central Java, base-level brokers locally called sabet "used rather slipshod methods in drawing up the lists, writing down people's names without knowing anything about their preferences, or without inquiring about which among them had been contacted by other teams." My brokers' survey found similar evidence. About $22 \%$ of brokers reported putting some or most of the names on their list without first consulting the voters.

Therefore, candidates expect that there will be a gap between the number of the names on the list to whom they distribute payments and the final number of votes they receive. They typically use a term derived from 
English, 'margin error,' (sic.) for describing this discrepancy, blaming 'extended brokers,' whose primary motivations are largely the pursuit of material rewards rather than long-term personal relationships with them. In my interviews, when candidates talked about this 'margin error' they typically referred to two sources of failure: (1) unreliability of voters who receive cash but who don't feel bound to repay with their votes and (2) failings of brokers, either due to rent-extraction by brokers or lack of capacity to identify and distribute benefits to voters who would reciprocate with votes. For their part, brokers typically point their finger at the transactional nature of voters who might vote for more 'generous' rivals.

Confronted by pervasive broker predation, some candidates claim to keep a tight rein on their success team members by doing multiple checks of the names on the lists. Realizing that the determinant of electoral success is the strength and reliability of brokerage networks, Saan Musthafa of the Democratic Party hired a Jakarta-based polling organisation to survey the effectiveness of his teams including by randomly sampling the people on the lists to check whether brokers had really talked to them (Interview, 25 April 2014). As I elaborate in more detail later in the chapter, however, candidates in general had very few instruments to monitor their brokers. Having seen that they were mostly unable to build tight and strong monitoring of their teams, candidates were responding by trying to pick brokers on the basis of intimate and personal contacts. However, due to the limited number of those who were emotionally and personally close to candidates, it was hard to avoid recruiting at least some brokers who lacked such ties.

Lastly, aside from the rent-seeking behaviour, another form of principalagency problems between candidates and brokers arose because some brokers actually didn't know their supposed clients well. My argument here is different from what Stokes and her colleagues' (2013) concluded-that brokers are necessary for clientelist exchange because they know their clients intimately. They argue (2013: 96) that "brokers are indeed involved in long-lived interactions with their neighbours and clients, interactions which - in the brokers' view—give them privileged information about the preferences and behaviours of individual voters." They offer detailed evidence from their broker survey in Argentina suggesting that nearly $80 \%$ of brokers claimed they would know when their neighbours, with whom they have a lot of dealings, voted against the candidate they were 'supposed' to support. Although this measure is likely to be distorted by social 
desirability bias, it is a simple measure of brokers' confidence in their ability to observe their clients' political preferences and actions.

Using a similarly worded question, my survey found a somewhat different picture in Indonesia. Indeed, $57 \%$ of brokers claimed to be able to infer whether their neighbours voted against their candidate. ${ }^{9}$ But the proportion of those who said they couldn't ascertain their clients' preferences was more than double the figure Stokes and her colleagues found in Argentina. As a follow-up, my broker survey asked those ground-level operatives, who claimed to know when a neighbour voted against a candidate they supported, how they did so? How could they work this out? The most frequent answer was derived from their day-to-day interactions with clients, enabling them to 'draw inferences from attitudes or affect' (37\%) such as being socially awkward, or through mannerisms or change of attitude, a look or gesture, or trying to avoid them. Others said they found out by 'asking around through direct communications about how a neighbour discusses any particular party/candidate' (31\%), whereas, others said that they had been simply informed by their neighbour $(5 \%)$, or based on information provided by other neighbours who stayed loyal $(5 \%)$, or through closely monitoring their data collection or internal surveys (3\%), or through the display of campaign posters or propaganda tools for another candidate in the voter's home $(3 \%)$.

But the key point is that in Indonesia there are widespread perceptions of ballot secrecy as evidenced in the relatively large number of brokers who recognise the difficulties they have in inferring their neighbours' vote choices. These findings are consistent with a widespread, almost 'doctrinal' belief that the country's elections must be 'direct, general, free, and confidential' (luber) that runs deep among voters. In my post-election survey of voters, we asked respondents whether, despite the principle that elections are confidential, influential people could discover how they voted. Only 19.7\% responded that this was "somewhat likely" or "very likely." The majority of respondents confirm the conventional wisdom that the secrecy of the ballot is difficult to violate, and even powerful persons in the neighbourhood wouldn't be able to find out how an individual voted.

In sum, brokers have both strong incentives and opportunities to shirk. The problems of predation and defection are especially severe in the case

\footnotetext{
${ }^{9}$ The question reads: "If you had a good relationship with your neighbours, when they voted for the candidate/party you didn't support, would you know about it?"
} 
of extended success teams whose commitments to the candidate are more transactional and whose members lack prior contacts with the candidate. As I explore in more detail in the following pages, many candidates pour out cash handouts en masse, but they ironically invest little effort in monitoring and disciplining brokers.

\subsection{How Stringent Was Candidates' Monitoring OF BROKERS AND VOTERS?}

As alluded earlier, candidates' capacity to monitor broker performance is weak. Surprisingly, my broker survey reveals that only $10 \%$ of the sampled brokers admitted that their actions were often monitored by their superiors in the team or campaign coordinators; $18 \%$ acknowledged that their campaign work was sometimes being monitored and a large majority felt they weren't monitored at all. Candidates are also vulnerable to rent-seeking behaviour by brokers because there are few punishment mechanisms for brokers who don't meet their target numbers of votes. A total of $56 \%$ of brokers admitted to failing to meet their targets. When asked a hypothetical question about the consequence if a broker fell far short of his or her target, ${ }^{10}$ only $7 \%$ of respondents said the failing broker would receive any negative treatment from the campaign coordinator or candidate. Among those who responded affirmatively, a follow-up question was asked about the form of negative treatment: the answers were that the failing broker would be subjected to verbal abuse $(30 \%)$, not invited to join success teams in the future $(28 \%)$, cut out of future pork-barrel projects $(20 \%)$, or not receive the money or goods that had been promised $(9 \%)$. All of this suggests that most candidates are unable to build stringent mechanisms to monitor or discipline their brokers.

Not only did candidates have few instruments to enforce discipline on their brokers, the brokers themselves had even fewer mechanisms for monitoring their voters to ensure that they kept their bargain to vote for the candidate. Asked what they could do when voters received gifts but voted for another candidate, the overwhelming majority of brokers said they couldn't do anything. Similarly, brokers couldn't do anything with voters who took the money but didn't even attend the polling station

\footnotetext{
${ }^{10}$ The question reads: "If there is a broker who didn't meet the target (for example, he/ she promised to generate 20 votes, but the candidate finally got only 2 votes at the polling station/village), did the broker receive certain negative treatments from the campaign coordinator or candidates concerned?"
} 
Table 6.6 What would you do when a recipient didn't come to the voting booth?

\begin{tabular}{lc}
\hline Response & $\%$ \\
\hline Nothing, I couldn't do anything & 73 \\
Ending the voter's chance to ask for help to the candidates & 8 \\
Not give the vote money/goods again in the next election & 7 \\
Ask for the money/goods to be returned & 3 \\
Reprimand them & 7 \\
Threaten them & 2 \\
\hline
\end{tabular}

Source: My survey of brokers, 30 September-25 October 2014

(Table 6.6). Only a few brokers reported they would scold or threaten those who just took the money but voted for other candidates.

Why did brokers seem to be pessimistic about enforcing their deal with voters? The answer primarily lies in the fact, already touched upon earlier in the chapter, that elections are free, and that ballot secrecy is strongly enforced in Indonesia, incentivising voters to behave opportunistically. My voters' survey reports very minimal rates of intimidation or violence from political campaigns, suggesting that both brokers and voters who were unable to comply with the bargain would rarely be targets of violence. An overwhelming majority (84\%) considered the 2014 election as 'fair and free' based on the exit polls run by Indikator, to which I am affiliated in which 1928 respondents were interviewed face to face immediately after casting their votes. ${ }^{11}$ There is widespread confidence that vote choices can be kept secret from politicians and their success teams. My postelection survey of voters asked respondents whether politicians could guess how they voted. A total of $74.8 \%$ of the sample responded this was "not at all likely" or "not very likely," while only $13.2 \%$ said it was "somewhat likely" or "very likely."

Likewise, when asked to name who else might be aware of how they voted, though they were allowed to provide multiple responses, only $2.3 \%$ of the sample responded that party or a candidate brokers could find out how they voted (Fig. 6.8). The modal answer is husband or wife (58.8\%) then followed by relatives (14\%), suggesting that many voters don't discuss their electoral choices with outsiders or, sometimes, even within the

\footnotetext{
${ }^{11}$ Available at http://indikator.co.id/uploads/20140411204045.Hasil_EP_Pileg_2014_ Update.pdf. Accessed 5 October 2016.
} 


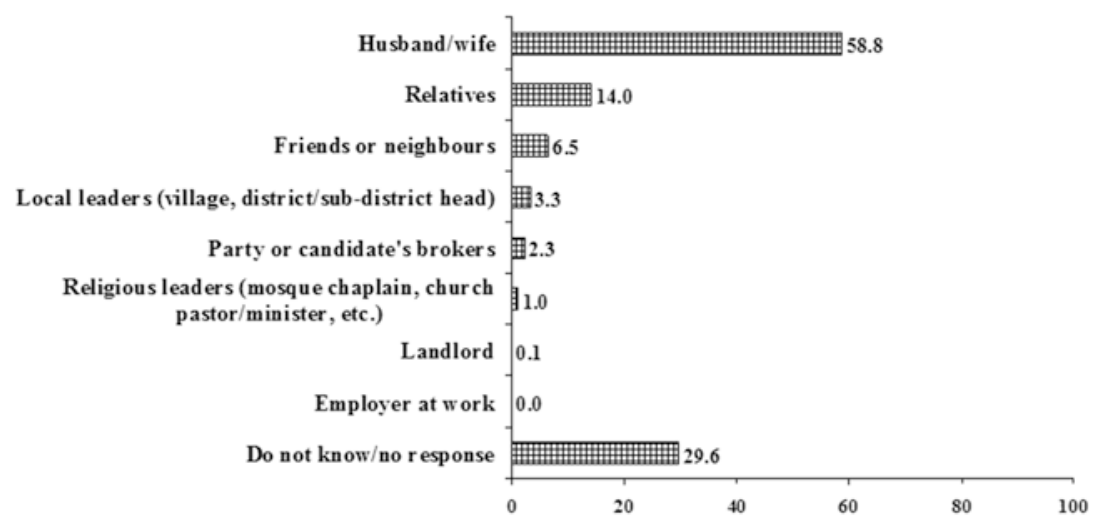

Fig. 6.8 Who else do you think is aware of how you voted? (\%). Source: My post-election survey, 22-26 April 2014

family. One senior PKB politician colourfully recounted a story of his neighbour from his hometown in Central Java who, despite receiving a lot of benefits from him, shamelessly requested additional compensation in return for his vote; the politician ironically noted, "Still, which candidate he finally cast his vote for was a mystery to me" (Interview, 20 April 2014). With echoes of earlier work by Aspinall and his collaborators (2015), much of what I see in Indonesia provides little support for Stokes' (2005) theory of "perverse accountability." She argues that instead of politicians being accountable to voters, where vote-buying transactions occur, voters are held accountable for their vote through direct and indirect coercion. This wasn't the case in Indonesia. Even those who take rewards don't lose their power to hold politicians accountable because political machines are unable to infer voters' behaviours; voters can still take money from a candidate and vote against him or her.

\subsection{CONCLUSION}

In this chapter, I have outlined that, unlike the comparative literature on vote buying which conventionally assumes that political parties play a central role in the distribution of material inducements, political parties in Indonesia have a relatively marginal role in electoral campaigns. Under Indonesia's open-list PR system, the influence of party organisation is lim- 
ited, and it is individual candidates who have more prominence in electioneering. Additionally, in settings like Indonesia where partisan ties are weak and where the personalised nature of voting requires co-partisans to compete against each other, candidates rely on more personalised rather than strictly party-based relationships. As a result, personal networks and non-party brokers play the critical role in grassroots campaigning.

At the outset of the chapter, I demonstrated that personal networks not only structured vote buying but also had significant impacts on (1) broker recruitment, (2) success team structures, and (3) targeting strategies. Personal networks shape how candidates recruit success team members and determine the structure of vote brokerage. More than two-thirds of sampled brokers knew the candidate personally prior to joining his/her success team. There are two logics underpinning this strategy. First is to minimise the problem of broker loyalty. Those who have personal connections with candidates are less likely to shirk. Second, from a purely strategic perspective, such brokers are more likely to campaign on the candidate's track record. The centrality of personal networks was also visible in targeting strategies. Brokers prioritised household members, close friends, and neighbours when collecting votes. When candidates and brokers started to exhaust the supply of voters who have personal connections to them, they move further afield in the search for both brokers and voters. Accordingly, a substantial amount of leakage-which occurs when people receive payment yet don't reciprocate with votes-occurred. Given that many beneficiaries were selected on the basis of personal networks, which were loosely connected to ideological proximity to the party or candidate, the potential for such slippage was great.

It is increasingly clear that buying votes was a risky game for candidates. Given their lack of mechanisms to monitor their brokers and the reality that many of them used 'extended success teams,' relying on at least some brokers with whom they lacked direct personal connections and who were more concerned with material payoffs, their vote-buying attempts were vulnerable to rent extraction by brokers. Fine-grained evidence from my unique broker survey combined with qualitative work demonstrates that rent-seeking behaviours among brokers were common in the 2014 legislative election. Nonetheless, candidates were quite relaxed about their brokers failing to meet vote targets, at least if they were successful in securing enough personal votes to win. Having realised that such rent-seeking behaviours are unavoidable and there are so many difficulties in enforcing the vote-buying contracts, candidates are tolerant if their brokers fall 
short, as long as they produce victory in the context of Indonesia's highly competitive electoral landscape. Finally, despite the personal networks helping to provide a mechanism to structure vote buying in Indonesia, they cannot escape from the problem of agency loss between candidates and brokers that is integral to electoral clientelism in many contexts.

There remains one major puzzle, however. If vote-buying efforts are so vulnerable to broker predation, as shown in this chapter, and the targeting is so misdirected, as already discussed in Chap. 5, why do candidates invest so heavily in it? The next chapter provides an answer to this question.

\section{BIBLIOGRAPHY}

Books, Journal Articles, and Unpublished Papers

Agresti, A. (2007) An Introduction to Categorical Data Analysis. New York: John Wiley \& Sons, Inc.

Alamsyah. (2016) Musi Banyuasin, South Sumatra: Nine Steps to Victory. In: E. Aspinall and M. Sukmajati (eds) Electoral Dynamics in Indonesia: Money Politics, Patronage and Clientelism at the Grassroots. Singapore: NUS Press.

Aspinall, E. (2014) When Brokers Betray: Social Networks and Electoral Politics in Indonesia. Critical Asian Studies 46(4): 545-570.

Aspinall, E., Davidson, M., Hicken, A., and Weiss, M. (2015) Inducement or Entry Ticket? Broker Networks and Vote Buying in Indonesia. Paper presented at American Political Science Association Conference, 3-6 September, San Francisco.

Aspinall, E. and Sukmajati, M. (eds) (2016) Electoral Dynamics in Indonesia: Money Politics, Patronage and Clientelism at the Grassroots. Singapore: NUS Press.

Aspinall, E., Rohman, N., Hamdi, A.Z., Rubaidi, and Triantini, Z. (2017) Vote Buying in Indonesia: Candidate Strategies, Market Logic and Effectiveness. Journal of East Asian Studies 17: 1-27.

Auyero, J. (2001) Poor People's Politics: Peronist Networks and the Legacy of Evita. Durham, NC: Duke University Press.

Diaz-Cayeros, A., Estévez, F., and Magaloni, B. (2012) Strategies of Vote Buying: Democracy, Clientelism and Poverty Relief in Mexico. Viewed at https://web. stanford.edu/ magaloni/dox/2012strategiesvotebuying.pdf. Accessed 17 October 2015.

Geertz, C. (1960) The Religion of Java. New York: The Free Press.

Hicken, A. (2007) How Do Rules and Institutions Encourage Vote Buying? In: F.C. Schaffer (ed) Elections for Sale: The Causes and Consequences of Vote Buying. Colorado: Lynne Rienner Publisher, Inc. 
Martel, M.U. (1968) Age-Sex Roles in American Magazine Fiction (1989-1955). In: B.L. Neugarten (ed) Middle Age and Aging: A Reader in Social Psychology. Chicago and London: Chicago University Press.

Rohman, N. (2016) Pati, Central Java: Targets, Techniques and Meanings of Vote Buying. In: E. Aspinall, and M. Sukmajati (eds) Electoral Dynamics in Indonesia: Money Politics, Patronage and Clientelism at the Grassroots. Singapore: NUS Press.

Stokes, S.C. (2005) Perverse Accountability: A Formal Model of Machine Politics with Evidence from Argentina. American Political Science Review 99(3): $315-325$.

- (2007) Is Vote Buying Undemocratic? In: F.C. Schaffer (ed) Elections for Sale: The Causes and Consequences of Vote Buying. Colorado: Lynne Rienner Publisher, Inc.

Stokes, S.C., Dunning, T., Nazareno, M., and Brusco, V. (2013) Brokers, Voters and Clientelism: The Puzzle of Distributive Politics. New York: Cambridge University Press.

Szwarcberg, M. (2015) Mobilizing Poor Voters: Machine Politics, Clientelism, and Social Networks in Argentina. New York: Cambridge University Press.

Triantini, Z.E. (2016) Blora, Central Java: Local Brokers and Vote Buying. In: E. Aspinall and M. Sukmajati (eds) Electoral Dynamics in Indonesia: Money Politics, Patronage and Clientelism at the Grassroots. Singapore: NUS Press.

Zarazaga, S.J.R. (2014) Brokers beyond Clientelism: A New Perspective through the Argentine Case. Latin American Politics and Society 56(3): 23-45.

Open Access This chapter is licensed under the terms of the Creative Commons Attribution 4.0 International License (http://creativecommons.org/licenses/ by $/ 4.0 /$ ), which permits use, sharing, adaptation, distribution and reproduction in any medium or format, as long as you give appropriate credit to the original author(s) and the source, provide a link to the Creative Commons licence and indicate if changes were made.

The images or other third party material in this chapter are included in the chapter's Creative Commons licence, unless indicated otherwise in a credit line to the material. If material is not included in the chapter's Creative Commons licence and your intended use is not permitted by statutory regulation or exceeds the permitted use, you will need to obtain permission directly from the copyright holder.

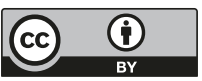

